\title{
Pengaruh Penambahan Air Lindi terhadap Laju Dekomposisi Sampah Daun yang dikomposkan dalam Vessel
}

\author{
Yahya Hanafi, Yulipriyanto, Bernadetta Ocatvia \\ Progam Studi Pendidikan Biologi, Universitas Ahmad Dahlan \\ Kampus III, J1. Prof. Dr. Soepomo, SH, Yogyakarta, 55164 Indonesia \\ surat elektronik: yahya.hanafi@pbio.uad.ac.id
}

\begin{abstract}
ABSTRAK
Sampah merupakan barang atau segala sesuatu yang dianggap sudah tidak berguna, tidak dipakai, tidak disenangi dan tidak dapat dipergunakan (tidak fungsional lagi). Sampah daun merupakan sampah organik terbanyak di lingkungan kampus Universitas Negeri Yogyakarta (UNY). Pengomposan secara alami berlangsung cukup lama, dengan penambahan aktivator dapat mempercepat proses pengomposan. Alternatif aktivator yang dapat digunakan yaitu air lindi dari hasil proses pengomposan sampah daun di rumah Kompos UNY. Melalui penelitian ini akan diungkap kemampuan mikroorganisme di dalam air lindi untuk mempercepat laju dekomposisi sampah daun dan mengetahui dinamika densitas bakteri-fungi.

Bahan utama penelitian yaitu sampah daun kelengkeng (Euphoria longana), daun ketepeng (Cassia tora L.), dan air lindi dari pengomposan di rumah kompos UNY. Penelitian ini memakai 6 taraf perlakuan air lindi, yaitu perlakuan $\mathrm{A}=$ kontrol (tanpa air lindi); $\mathrm{B}=2,2$ liter ; $\mathrm{C}=3,2$ liter ; $\mathrm{D}=4,2$ liter ; $\mathrm{E}=5,2$ liter ; $F=6,2$ liter, jumlah volume sampah daun $8 \mathrm{~kg}$ setiap perlakuan. Penelitian dilakukan dengan skala kecil dalam ressel (ember) berukuran 8 liter selama 70 hari di rumah kompos UNY. Laju dekomposisi sampah daun ditentukan dari besarnya penurunan rasio $\mathrm{C} / \mathrm{N}$ pada akhir pengomposan.

Penambahan air lindi sebesar 5,2 liter dalam $8 \mathrm{~kg}$ sampah daun paling optimum menurunkan rasio $\mathrm{C} / \mathrm{N}$ sebesar 43,18\% dengan lama waktu pengomposan selama 70 hari. Dinamika densitas bakteri- fungi berkaitan dengan penurunan rasio C/N, kadar Karbon (C), kadar Bahan Organik (BO), kadar air, bobot kompos dan peningkatan kadar Nitrogen (N), kadar Phospor (P), kadar Kalium (K), dan pH kompos..
\end{abstract}

Kata kunci: sampah daun, laju dekomposisi, air lindi, rasio $\mathrm{C} / \mathrm{N}$

\section{Pendahuluan}

Sampah organik di lingkungan kampus UNY didominasi oleh sampah daun yang berasal dari pepohonan di lingkungan kampus UNY. Pengelolaan sampah daun di UNY dilakukan dengan cara pengomposan di rumah kompos UNY. Produk utama pengomposan daun di rumah kompos UNY adalah kompos yang dapat digunakan untuk media tanam dan memperbaiki sifat kimia, fisika, dan biologi tanah. Selain itu, proses pengomposan sampah daun di rumah kompos UNY menghasilkan produk sampingan yaitu berupa air lindi dari proses pengomposan. Air lindi merupakan air yang dihasilkan dari proses perlindian (leaching) pengomposan, dimana air mengalami perkolasi melalui material-material yang bersifat permeabel.

Proses pengomposan di rumah kompos UNY dilakukan secara alami tanpa penambahan obat atau bahan kimia untuk mempercepat proses pengomposan.
Bahan utama yang dikomposkan didominasi oleh daun kelengkeng (Euphoria longana). Proses pengomposan sampah daun berjalan cukup lama yaitu sekitar 4-5 bulan sampai diperoleh kompos matang yang siap pakai. Lama proses pengomposan tergantung pada beberapa faktor, antara lain: bahan yang dikomposkan, ukuran bahan, aerasi, kelembaban, rasio $\mathrm{C} / \mathrm{N}, \mathrm{pH}$, temperatur, dan mikroorganisme. Diantara faktor-faktor tersebut, faktor mikroorganisme merupakan faktor yang sangat berperan dalam proses pengomposan.

Menurut Landau (2002 dalam Widawati, 2005: 240), suatu material seperti limbah serasah dan rumput, membutuhkan waktu sangat lama untuk menjadi pupuk organik, sehingga untuk mempercepat proses tersebut perlu dibantu aktivator atau inokulan sebagai katalisator. Aktivator adalah mikroba dekomposer atau zat kimia (ammonium sulfat, asam amino, sodium nitrat, urea, dan ammonia) yang berperan sebagai katalisator untuk mempercepat proses pengomposan. Penambahan 
aktivator atau inokulan pada pembuatan kompos merupakan bagian dari usaha untuk mempercepat proses pengomposan, meskipun sesungguhnya pada bahan material pembentuk kompos sendiri sudah terkandung banyak mikroba, khususnya yang berperan dalam perombakan zat kimia. Salah satu alternatif aktivator yang murah, tanpa biaya, dan ramah lingkungan adalah dengan menggunakan air lindi hasil proses pengomposan. Air lindi merupakan air yang dihasilkan dari proses pengomposan sehingga mengandung mikroba-mikroba yang memiliki kemampuan dalam mendekomposisi material organik.

Dalam penelitian ini dilakukan pemberian aktivator air lindi untuk mempercepat laju dekomposisi sampah daun. Sampah daun yang dikomposkan dalam penelitian ini berasal dari pohon kelengkeng (Euphoria longana) dan ketepeng (Cassia tora L.). Aktivator air lindi diharapkan dapat menyuplai mikroba yang berperan dalam proses pengomposan sehingga dapat meningkatkan laju dekomposisi pengomposan. Melalui penelitian ini akan diungkap kemampuan mikroorganisme di dalam air lindi untuk mempercepat laju dekomposisi sampah daun dan mengetahui dinamika densitas bakteri-fungi dalam air lindi. Hasil penelitian diharapkan dapat memberikan kontribusi terhadap pengembangan pengomposan di UNY untuk mewujudkan kampus yang ramah lingkungan, hijau, bersih, dan menjadi contoh pengelolaan sampah secara mandiri.

\section{Metode Penelitian}

Jenis penelitian adalah eksperimental sederhana dengan menggunakan enam perlakuan air lindi yaitu : A $=$ kontrol $; \mathrm{B}=2,2$ liter $; \mathrm{C}=3,2$ liter $; \mathrm{D}=4,2$ liter ; $\mathrm{E}=5,2$ liter $; \mathrm{F}=6,2$ liter. Bahan penelitian menggunakan sampah daun kelengkeng (Euphoria longana) dan ketepeng (Cassia tora L.), dan air lindi dari hasil pengomposan daun di rumah kompos UNY. Penelitian menggunakan ember (vessel) sebagai tempat untuk pengomposan. Penelitian dilakukan selama 70 hari di rumah kompos UNY.

\section{Prosedur Kerja}

\section{Tahap persiapan}

a. Penyiapan tempat

Dipersiapkan 6 buah ember ukuran tinggi 70 $\mathrm{cm}$, diameter $40 \mathrm{~cm}$, kemudian diberi label pada ember sesuai dengan perlakuan dan ember diletakkan pada tempat yang kering dan terlindung yaitu di rumah kompos UNY.

b. Penyiapan bahan

I) Sampah Daun

Dikumpulkan daun kelengkeng (Euphoria longana) dan ketepeng (Cassia tora L.), ke yang baru jatuh dari pohon yang berada di lingkungan kampus FMIPA UNY. Dipilah dari sampah daun dari kerikil, plastik. Daun dicacah dengan menggunakan mesin pencacah. Dicampur daun kelengkeng dan daun ketepeng yang telah dicacah. Perbandingan antara daun kelengkeng (Euphoria longana) dan ketepeng (Cassia tora L.), yaitu satu ember daun kelengkeng (Euphoria longana) ukuran 8 liter dengan satu ember daun ketepeng (Cassia tora L.) ukuran 8 liter(I : I). Ditimbang daun yang telah dicampur tersebut seberat $8 \mathrm{~kg}$ untuk setiap perlakuan dan diletakkan di atas lantai yang diberi alas plastik untuk masing-masing perlakuan.

2) Air Lindi

Air lindi dalam sumur penampung di rumah kompos UNY diaduk-aduk dengan menggunkan kayu untuk menghomogenkan. Diambil air lindi sesuai dengan kadar yang diberikan pada setiap perlakuan.

\section{Tahap Perlakuan}

a. Pemberian air lindi dilakukan di luar vessel (ember) untuk pengomposan yaitu dengan cara air lindi diberikan secara bertahap, kemudian dicampur secara merata pada bahan yang dikomposkan dan dimasukkan ke dalam vessel (ember).

b. Pada hari ke-0 dilakukan pengambilan data pada setiap perlakuan.

c. Setelah dilakukan pengambilan data pada masingmasing perlakuan kemudian bahan yang dikomposkan pada setiap vessel ditutup dengan kain goni. Vessel diletakkan di tempat yang terbuka dan terlindung yaitu di rumah kompos UNY.

d. Bahan dikomposkan selama 70 hari secara aerob, setiap I minggu dilakukan pembalikan tumpukan pada setiap perlakuan untuk menjaga aerasi.

\section{Hasil dan Pembahasan}

\section{Rasio C/N}

Rasio $\mathrm{C} / \mathrm{N}$ merupakan parameter utama dalam penelitian ini untuk mengetahui laju dekomposisi sampah daun. Rasio $\mathrm{C} / \mathrm{N}$ diukur pada awal pengomposan yaitu hari ke-0 dan pada akhir proses pengomposan yaitu hari ke-70 ditunjukkan pada Gambar I.

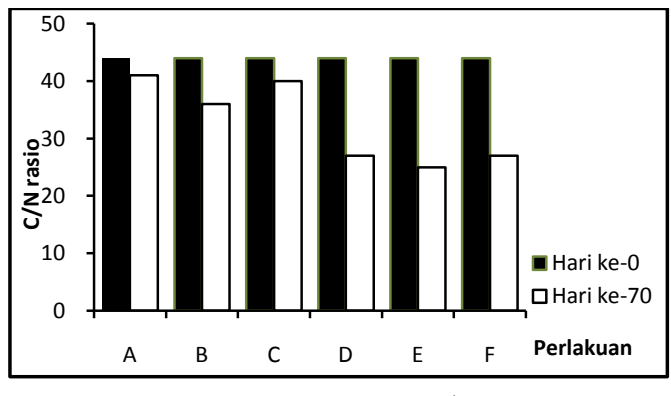

Gambar I. Grafik Penurunan Rasio C/N pada hari ke-70

Keterangan: A: kontrol (tanpa air lindi); B: 2,2 liter air lindi; C: 3,2 liter air lindi; D: 4,2 liter air lindi; E: 5,2 liter air lindi; F: 6,2 liter air lindi 
Laju dekomposisi sampah daun diketahui berdasarkan besarnya penurunan rasio $\mathrm{C} / \mathrm{N}$ yang terjadi selama proses pengomposan. Semakin besar penurunan rasio $\mathrm{C} / \mathrm{N}$ yang terjadi, maka semakin cepat laju dekomposisinya. Rasio C/N akhir kompos pada semua perlakuan mengalami penurunan dibandingkan dengan rasio $\mathrm{C} / \mathrm{N}$ awal (Gambar I). Adanya penurunan rasio $\mathrm{C} / \mathrm{N}$ menunjukkan selama proses pengomposan terjadi dekomposisi oleh mikroorganisme.

Penurunan rasio $\mathrm{C} / \mathrm{N}$ yang besar terjadi pada perlakuan D,E dan $\mathrm{F}$ karena jumlah air lindi yang diberikan lebih banyak sehingga mikroorganisme dengan kemampuan tinggi sebagai dekomposer jumlahnya semakin banyak. Semakin besar penurunan rasio $\mathrm{C} / \mathrm{N}$ maka aktivitas mikroorganisme juga semakin tinggi dan laju dekomposisinya semakin cepat.

Sumber karbon (C) yang terdapat dalam bahan organik akan digunakan bakteri sebagai sumber energi untuk melakukan proses metabolisme. Bakteri akan terus menerus menggunakan karbon (C) sebagai sumber energinya sehingga jumlah karbon yang terkandung dalam bahan yang dikomposkan akan terus berkurang. Jumlah karbon yang terus berkurang tersebut mengakibatkan rasio $\mathrm{C} / \mathrm{N}$ juga akan semakin berkurang.

\section{Kadar Nitrogen $(\mathrm{N})$}

Kadar Nitrogen $(\mathrm{N})$ bahan dihitung pada awal pengomposan hari ke-0 dan pada akhir pengomposan hari ke-70. Kadar Nitrogen (N) diukur untuk mengetahui perubahan unsur makro di dalam kompos ditunjukkan pada Gambar 2.

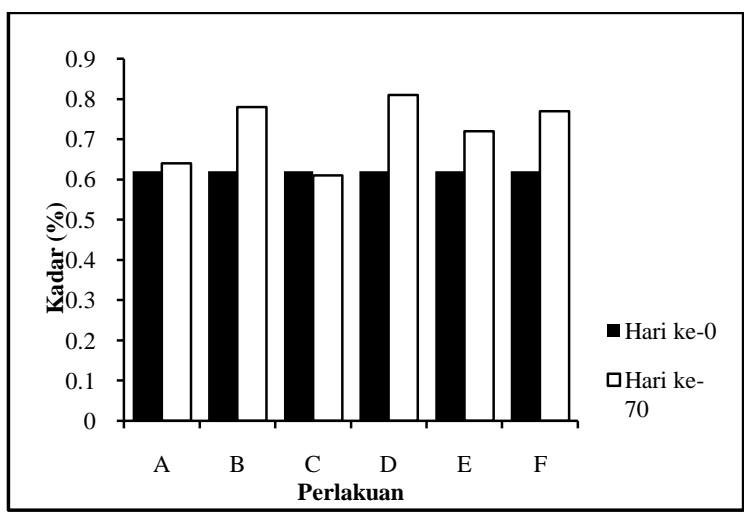

Gambar 2. Grafik Peningkatan kadar Nitrogen (N) pada hari ke-70

Keterangan :

A: kontrol (tanpa air lindi); B: 2,2 liter air lindi; C: 3,2 liter air lindi;

D: 4,2 liter air lindi; E: 5,2 liter air lindi; F: 6,2 liter air lindi

Berdasarkan gambar 2, dapat diketahui bahwa peningkatan kadar nitrogen $(\mathrm{N})$ terbesar adalah pada perlakuan D dan terkecil adalah pada perlakuan C. Kadar nitrogen $(\mathrm{N})$ menunjukkan kandungan nitrogen total dalam bahan-bahan organik. Secara umum kadar nitrogen $(\mathrm{N})$ akhir pada hari ke-70 mengalami peningkatan dibandingkan dengan kadar nitrogen pada awal pengomposan, kecuali pada perlakuan C yang mengalami penurunan sebesar I,6\% (Gambar 2). Peningkatan kadar nitrogen menunjukkan selama proses pengomposan terjadi nitrifikasi oleh bakteri Nitrobacter dan Nitrosomonas. Sesuai dengan teori, bahwa presentase kadar nitrogen total akan mengalami peningkatan selama proses pengomposan berlangsung. Reaksi nitrifikasi adalah reaksi perubahan ammonia $\left(\mathrm{NH}_{4}-\right.$ $\mathrm{N})$ dioksidasi menjadi nitrit $\left(\mathrm{NO}_{2}-\mathrm{N}\right)$ oleh Nitrosomonas dan nitrit dioksidasi menjadi nitrat $\left(\mathrm{NO}_{3}-\mathrm{N}\right)$ oleh Nitrobacter. Secara umum pemberian air lindi dalam pengomposan sampah daun akan meningkatkan kadar Nitrogen $(\mathrm{N})$ total dari kompos yang dihasilkan.

\section{Kadar Fosfor (P)}

Pengukuran kadar Fosfor (P) dilakukan pada bahan awal hari ke-0 dan pada akhir proses pengomposan hari ke-70 ditunjukkan pada Gambar 3.

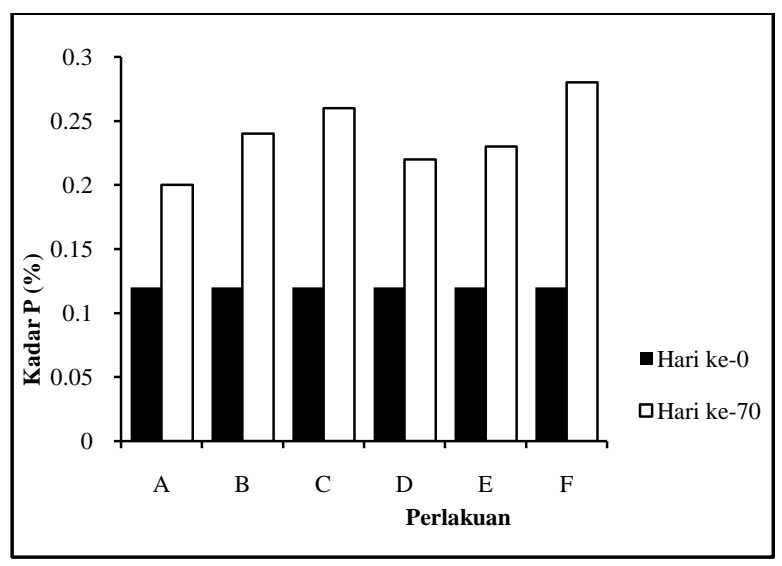

Gambar 3. Grafik Peningkatan kadar Fosfor (P) hari ke-70

\section{Keterangan :}

A: kontrol (tanpa air lindi); B: 2,2 liter air lindi; C: 3,2 liter air lindi, D: 4,2 liter air lindi; E: 5,2 liter air lindi; F: 6,2 liter air lindi

Berdasarkan Gambar 3 tersebut dapat diketahui bahwa peningkatan kadar $\mathrm{P}$ yang terjadi mencapai lebih dari 100\%. Peningkatan kadar P tertinggi yaitu pada perlakuan $\mathrm{F}$ (6,2 liter air lindi) sebesar $133,33 \%$ dan terendah pada perlakuan A (kontrol) sebesar 66,67\%. Phosphor (P) merupakan salah satu unsur makro di dalam kompos yang diukur dalam bentuk $\mathrm{P}_{2} \mathrm{O}_{5}$. Tanaman akan menggunakan Fosfor $(\mathrm{P})$ dalam bentuk $\mathrm{H}_{2} \mathrm{PO}_{4}$. Kadar Fosfor (P) akhir (hari ke-70) pada semua perlakuan mengalami peningkatan dibandingkan kadar Fosfor (P) pada awal pengomposan. Secara umum, dapat dilihat kecenderungan pola pada grafik peningkatan kadar Fospor $(\mathrm{P})$ yaitu peningkatan kadar Fosfor $(\mathrm{P})$ akan sebanding dengan pemberian air lindi. Sehingga, semakin banyak air lindi yang diberikan maka semakin tinggi peningkatan kadar Fosfor $(\mathrm{P})$ yang terjadi.

Kadar Fosfor $(\mathrm{P})$ setiap perlakuan dapat meningkat karena selama dekomposisi berlangsung terjadi 
mineralisasi yaitu perubahan unsur hara dari bentuk organik menjadi anorganik. Proses dekomposisi secara aerobik akan menghasilkan produk salah satunya berupa hara, termasuk di dalamnya adalah unsur Fosfor (P). Sehingga, kadar Fosfor (P) total akan terus mengalami peningkatan selama proses pengomposan berlangsung.

\section{Kadar Kalium}

Kadar Kalium $(\mathrm{K})$ dihitung pada hari ke-0 dan pada akhir proses pengomposan hari ke-70 ditunjukkan pada Gambar 4.

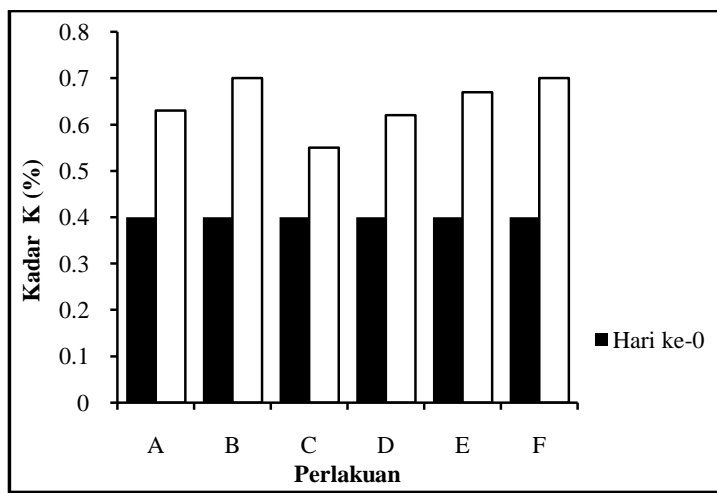

Gambar 4. Grafik Peningkatan kadar Kalium (K) pada hari ke-70

\section{Keterangan :}

A: kontrol (tanpa air lindi); B: 2,2 liter air lindi; C: 3,2 liter air lindi D: 4,2 liter air lindi; E: 5,2 liter air lindi; F: 6,2 liter air lindi

Berdasarkan Gambar 4, dapat diketahui bahwa peningkatan kadar Kalium $(\mathrm{K})$ pada setiap perlakuan berbeda-beda. Kadar Kalium (K) dalam kompos diukur dalam bentuk $\mathrm{K}_{2} \mathrm{O}$. Tanaman menggunakan Kalium (K) dalam bentuk $\mathrm{K}^{+}$. Kadar Kalium merupakan salah satu parameter untuk mengetahui kualitas kompos yang dihasilkan. Kadar Kalium (K) pada akhir pengomposan (hari ke-70) dari semua perlakuan mengalami peningkatan dibandingkan kadar Kalium (K) pada awal pengomposan. Secara umum, dapat dilihat kecenderungan pola pada grafik peningkatan kadar Kalium (K) (Gambar 4) yaitu peningkatan kadar Kalium $(\mathrm{K})$ akan sebanding dengan pemberian air lindi.

Kadar Kalium (K) setiap perlakuan meningkat karena selama dekomposisi berlangsung terjadi proses mineralisasi yaitu perubahan unsur hara dari bentuk organik menjadi anorganik. Proses dekomposisi secara aerobik akan menghasilkan produk salah satunya berupa hara, termasuk di dalamnya adalah unsur Kalium (K). Sehingga, kadar Kalium (K) total akan terus mengalami peningkatan selama proses pengomposan berlangsung. Hasil kadar Kalium (K) kompos dari penelitian ini tidak menunjukkan adanya keterkaitan dengan parameter lain seperti kadar Nitrogen (N), kadar Fosfor (P), kadar karbon (C), rasio $\mathrm{C} / \mathrm{N}$.

\section{Bakteri}

Jumlah bakteri yang hidup dalam tumpukan kompos akan berubah-ubah menyesuaikan dengan kondisi lingkungannya. Untuk mengetahui jumlah kisaran bakteri yang hidup dalam setiap tumpukan kompos pada masing-masing perlakukan maka dilakukan penghitungan jumlah bakteri. Penghitungan jumlah bakteri dilakukan dua minggu sekali, bersama dengan penghitungan jumlah fungi ditunjukkan pada Gambar 5.

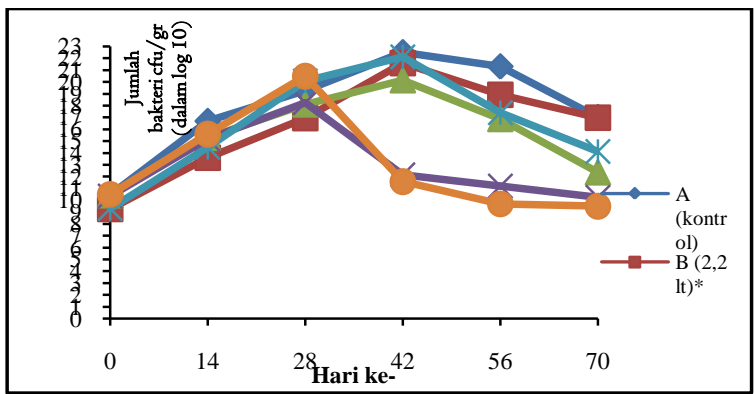

Gambar 5. Grafik jumlah bakteri selama proses pengomposan

Keterangan : *Volume air lindi

Berdasarkan Gambar 5, jumlah bakteri pada setiap perlakuan mengalami kenaikan, kemudian akan mencapai titik optimum pada waktu tertentu dan selanjutnya mengalami penurunan. Pada saat mencapai titik optimum, jumlah bakteri adalah paling tinggi jumlahnya selama pengomposan dan pada saat itu terjadi aktivitas dekomposisi yang paling aktif oleh bakteri. Titik optimum perlakuan A, B, C, dan E yaitu pada hari ke-42 pengomposan. Titik optimum perlakuan D dan F yaitu pada hari ke-28 pengomposan. Pemberian air lindi dengan jumlah yang berbeda-beda akan berpengaruh terhadap kecepatan jumlah bakteri mencapai titik optimum. Pola atau kecenderungan grafik jumlah bakteri yaitu grafik yang terbentuk pada setiap perlakuan memiliki titik optimum pada waktu tertentu. Berdasarkan pola grafik diatas, maka dapat diketahui bahwa penurunan jumlah bakteri paling besar terjadi pada perlakuan $\mathrm{F}$ (6,2 liter). Jumlah bakteri yang terlibat selama proses pengomposan akan berpengaruh terhadap kecepatan dekomposisi.

Secara umum, pada semua perlakuan jumlah bakteri turun pada akhir proses pengomposan karena perannya telah digantikan oleh Actinomycetes. Actinomycetes hidup pada akhir proses pengomposan dan akan menghasilkan antibiotik yang menghambat perkembangan bakteri sehingga jumlah bakteri akan terus berkurang. Proses pengomposan yang terjadi pada setiap perlakuan adalah secara aerobik karena proses pengomposan berlangsung dengan menggunakan oksigen. Ketersediaan oksigen dalam tumpukan dijaga dengan melakukan pembalikan setiap satu minggu sekali sehingga selama pengomposan selalu terdapat udara segar dan kondisi anaerobik dapat dihindari. Proses reaksi aerob, yaitu :

$$
\begin{aligned}
& \mathrm{O}_{2}+\mathrm{CH}_{2} \mathrm{O}------->\mathrm{CO}_{2}+\mathrm{H}_{2} \mathrm{O} \\
& \mathrm{C}_{6} \mathrm{H}_{12} \mathrm{O}_{6}+6 \mathrm{O}_{2} \longrightarrow 6 \mathrm{CO}_{2}+6 \mathrm{H}_{2} \mathrm{O}
\end{aligned}
$$


Proses penguraian diatas menghasilkan panas, air $\left(\mathrm{H}_{2} \mathrm{O}\right)$, ammoniak $\left(\mathrm{NH}_{3}\right)$, hara, dan karbon dioksida $\left(\mathrm{CO}_{2}\right)$. Air akan menguap keluar tumpukan sehingga dapat mengurangi kadar air tumpukan selama proses pengomposan. Karbon dioksida juga akan menguap keluar dari tumpukan kompos. Panas yang dihasilkan dari metabolisme bakteri sebagian dilepaskan ke dalam tumpukan yang akan menyebabkan temperatur tumpukan naik dan sebagian dilepaskan keluar tumpukan.

Bakteri menggunakan karbon dari material bahan organik sebagai sumber energi dan menggunakan nitrogen sebagai sumber penyusun protein. Bakteri membutuhkan nitrogen untuk mempercepat pertumbuhannya. Nitrogen harus tersedia dalam jumlah yang cukup, jika terlalu sedikit maka pertumbuhan bakteri tidak maksimal sehingga proses dekomposisi akan berjalan lambat. Sebaliknya jika jumlah nitrogen terlalu banyak maka pertumbuhan bakteri sangat cepat dan akan menyebabkan kondisi anaerobik dalam pengomposan sehingga akan menghasilkan bau dari nitrogen yang berubah menjadi gas amoniak.

\section{Jumlah Fungi}

Fungi merupakan salah satu mikroorganisme yang berperan dalam dekomposisi bahan selama proses pengomposan ditunjukkan pada Gambar 6 .

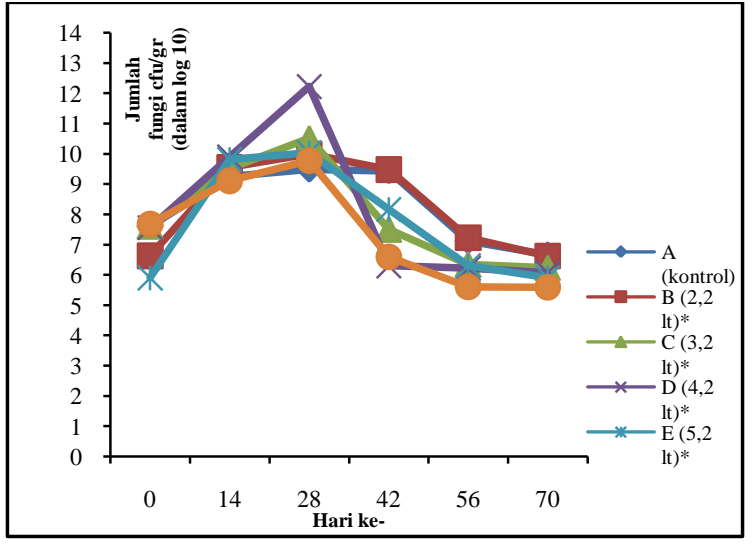

Gambar 6. Grafik jumlah Fungi selama proses pengomposan

Keterangan : *volume air lindi

Berdasarkan Gambar 6, dapat dilihat pola atau kecenderungan jumlah fungi selama proses pengomposan berlangsung. Pola atau kecenderungan jumlah fungi selama proses pengomposan sama dengan kecenderungan jumlah bakteri, yaitu jumlah fungi mengalami kenaikan mencapai titik optimum pada waktu tertentu kemudian selanjutnya akan mengalami penurunan. Titik optimum yang dicapai oleh semua perlakuan yaitu pada hari ke-28 pengomposan. Pemberian air lindi berpengaruh terhadap pola atau kecenderungan jumlah fungi pada setiap perlakuan dan tidak menunjukkan pengaruh yang besar terhadap jumlah fungi pada setiap perlakuannya.
Fungi adalah mikroorganisme selain bakteri dan Actinomycetes yang berperan dalam proses pengomposan. Fluktuasi perubahan jumlah bakteri dan fungi berjalan secara beriringan, yaitu kenaikan jumlah bakteri juga diikuti kenaikan jumlah fungi dan penurunan jumlah bakteri juga akan diikuti penurunan jumlah fungi. Penurunan jumlah fungi di akhir pengomposan disebabkan Actinomycetes banyak berperan di akhir pengomposan. Fungi menggunakan karbon (C) sebagai sumber energi dan nitrogen untuk mempercepat pertumbuhannya. Fungi dapat menguraikan senyawa-senyawa yang tahan dan tidak dapat diuraikan oleh bakteri misalnya selulosa dan lignin. Fungi menguraikan selulosa dengan sempurna dan hanya menghasilkan $\mathrm{CO}_{2}$, pigmen-pigmen tertentu, sejumlah subtansi (zat) sel mikrobial. Sekitar $30-40 \%$ dari selulosa yang dipecah oleh organisme pemisah (decomposing organism) diubah ke dalam bahan sel.

\section{Bobot Kompos}

Bobot kompos menjadi salah satu parameter untuk menunjukkan terjadi proses dekomposisi selama pengomposan. Bobot yang diukur pada setiap perlakuan adalah bobot basah kompos. Pengukuran bobot kompos dilakukan satu minggu sekali, bersama dengan pengukuran $\mathrm{pH}$ dan pembalikan kompos. Grafik bobot kompos selama proses pengomposan ditunjukan pada Gambar 7.

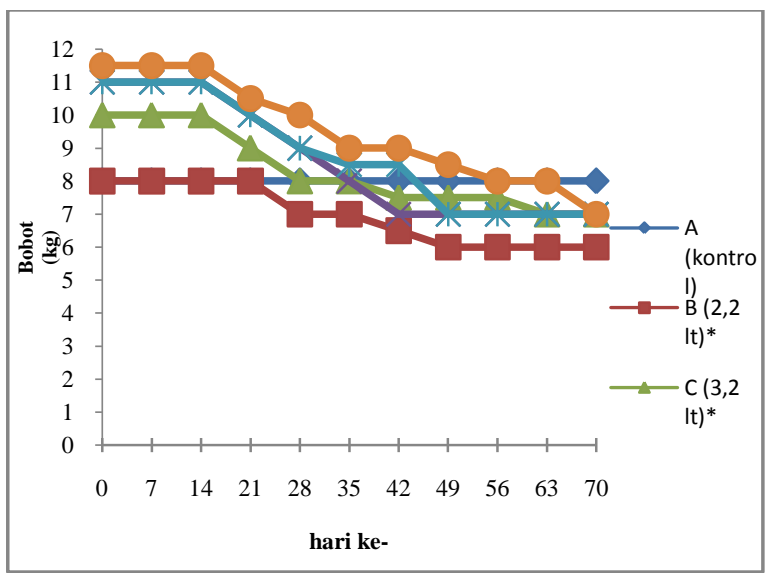

Gambar 7. Grafik bobot kompos selama proses pengomposan

Keterangan : volume air lindi

Bobot awal (hari ke-0) pada setiap perlakuan berbeda-beda karena volume air lindi yang diberikan pada setiap perlakuan berbeda sehingga akan berpengaruh terhadap bobot pada setiap perlakuannya.Berdasarkan gambar 5, dapat diketahui bahwa secara umum bobot bahan organik mengalami penurunan jika dibandingkan dengan bobot masingmasing perlakuan pada awal proses pengomposan (hari ke-0). Berkurangnya bobot kompos menandakan terjadi dekomposisi selama proses pengomposan berlangsung. Presentase penurunan bobot kompos setiap perlakuan dapat memberikan suatu pola, yaitu presentase penurunan bobot kompos berbanding lurus 
dengan taraf air lindi. Semakin banyak air lindi yang diberikan maka presentase penurunan bobot kompos akan semakin besar. Presentase penurunan paling besar terjadi pada perlakuan $\mathrm{F}$ yaitu dengan pemberian 6,2 liter air lindi (Gambar 7).

Penyusutan bobot kompos berkaitan dengan penurunan tinggi tumpukan kompos. Apabila reduksi bobot sampah cepat turun maka tinggi tumpukan akan turun pula. Hal tersebut disebabkan selama proses pengomposan mikroorganisme mencerna bahan organik diuraikan menjadi unsur-unsur sederhana yang dapat diserap oleh mikroorganisme, sehingga ukuran bahan yang dikomposkan berubah menjadi partikelpartikel kecil dan menyebabkan volume tumpukan menyusut salama proses pencernaan tersebut. Bobot kompos juga akan berkurang karena proses pencernaan oleh mikroorganisme menghasilkan panas yang menguapkan kandungan air dan $\mathrm{CO}_{2}$ dalam sampah.

\section{Simpulan}

Penambahan air lindi sebesar 5,2 liter dalam $8 \mathrm{~kg}$ sampah daun paling optimal menurunkan rasio $\mathrm{C} / \mathrm{N}$ sebesar $43,18 \%$ dengan lama waktu pengomposan selama 70 hari.

Dinamika densitas bakteri- fungi pada setiap tahapan waktu berkaitan dengan penurunan rasio $\mathrm{C} / \mathrm{N}$, kadar Karbon (C), kadar Bahan Organik (BO), kadar air, bobot kompos dan peningkatan kadar Nitrogen (N), kadar Fosfor (P), kadar Kalium (K), dan $\mathrm{pH}$ kompos.

\section{Daftar Pustaka}

Anonim. 200I. Compost Microbiologyand the Soil Food Web. Diakses Selasa, 03 November 2009 jamI 3.33 WIB. www.ciwmb.ca.gov/publications/organics/44200013

Anonim. 2005. pendahuluan kms. Diakases Senin, 20 oktober 2008 jam I6.58 WIB.

www.ipb.ac.id/userspace/download.php?id $=$ s/e/setyo/ $8 \mathrm{e} 3 \mathrm{e} 44 \mathrm{I}$

Ansori, T. 2005. Bahan Organik Tanah. Diakses Senin, I6 November 2009jamI4.I IWIB.elisa.ugm.ac.id/files/cahyonoagus/h DXaI7zE/tugas\%20ith\%20kul.doc

Atlas, R.M., dan Bartha, R. 1987. Microbial Ecology: Fundamentals and Applications. Second Edition. California : The Benjamin Cummings Publishing Company, Inc.

Deacon, J.W. I984. Modern Mycology. Third Edition. Edinburg : Blackwell Science Ltd.

Dindal, D.L. 1982. Compost Ecology and Management. $A$ Journal of Organic and Sustainable Agriculture. V.8, No. I \& 2I982. New York: Community Relations Office. Hal : I-5.
Grahayanti,Y.A.,Purwanti, I.P. 2006. Pengaruh Penambahan Kotorana Ayam dan Mikroorganisme M-I6 Dalam Pengomposan Sampah Kota Secara Semi An aerobik. Diakases Rabu, 25 Februari 2009 jam I I.00 WIB. mmt.its.ac.id/library/wpcontent/uploads/2008/I I/prosiding-yuniar-mtl.pdf

Hadiwiyoto. S, 1983. Penanganan dan Pemanfaatan Sampah. Jakarta : Yayasan Idayu.

Isroi. 2005. Pengomposan Limbah Padat Organik. Bogor : Balai Penelitian Bioteknologi Perkebunan Indonesia.

Kanti, A. 2007. Penapisan Khamir Selulolitik Cryptococcus Sp. Yang Diisolasi Dari Tanah Kebun Biologi Wamena, Jaya Wijaya, Propinsi Papua. Diakses Senin, I6 November 2009 jam I4.52 WIB. ejournal.unud.ac.id/abstrak/naskah\%20atit\%20kamir\% 20_4_rtf.pdf

Kutzner, J.H. Microbiology of Composting. Diakses Selasa, 03 November 2009 jam I3.26 WIB. www.wileyvch.de/books/biotech/pdf/vIIc_comp.pdf

Outerbridge, O. I991. Limbah Padat di Indonesia : Masalah atau Sumber Daya Jakarta: Yayasan Obor Indonesia.

Prasetyo, W.A. 2008. Uji Mikrobiologis Kompos Organik(Hasil Pengomposan Dengan Penambahan Limbah Tomat). Surakarta : Fakultas Keguruan dan Ilmu Pendidikan Universitas Muhammadiyah Surakarta.

Rizaldi, R. 2008. Pengelolaan Sampah Secara Terpadu di Perumahan Dayu Permai. Yogyakarta : Jurusan Teknik Lingkungan Fakultas Teknik Sipil Dan Perencanaan Universitas Islam Indonesia.

Rochaeni, A., Rusmaya, D., dan Hartini, K.P. 2003. Pengaruh Agitasi Terhadap Proses Pengomposan Sampah Organik. INFOMATEK. Volume 5 Nomor 4 Desember 2003. Bandung: Jurusan Teknik Lingkungan Fakultas Teknik Universitas Pasundan. Hal : I77-I86

Saraswati, R dan Husen, E. Prospek Penggunaan Pupuk Hayati Pada Sawah Bukaan Baru. Diakses Senin, 16 November 2009 jam I5.07 WIB.

balittanah.litbang.deptan.go.id/sawah\%20bukaan\%20ba ru\%2008.pdf

Saraswati R., Santosa, E., dan Yuniarti, E. Organisme Perombak Bahan Organik. Diakses Senin, I6 November 2009 jam I4.27 WIB.

balittanah.litbang.deptan.go.id/dokumentasi/buku/pup uk/pupukIO.pdf

Saraswati, R dan Sumarno.2008. Pemanfaatan Mikroba Penyubur Tanah sebagai Komponen Teknologi Pertanian. Jurnal Iptek Tanaman Pangan. Vol. 3 No.I 2008. Hal : 4I-58.

Schmidt, K. 1994. Mikrobiologi Umum. Edisi Keenam. Yogyakarta : Gadjah Mada University Press.

Siburian, R. 2007. Pengaruh Konsentrasi Dan Waktu Inkubasi Em4 Terhadap Kualitas Kimia Kompos. Diakses hari Senin, 23 Februari 2009 jam I4.08. ejournal.unud.ac.id/abstrak/pengaruhlkp.pdf 